\title{
Needs of Indonesian Short Story Writing Material: A Case Study of Foreign Students at ACS School Jakarta
}

\author{
Tri Maryanto ${ }^{\mathrm{a} 1}$, Endry Boeriswati ${ }^{\mathrm{b} 2}$, dan Liliana Muliastuti ${ }^{\mathrm{b3}}$ \\ ${ }^{a}$ Sekolah ACS Jakarta, Indonesia \\ ${ }^{b}$ State University of Jakarta, Indonesia \\ 1'trian82@gmail.com, ${ }^{2}$ endry.boeriswati@unj.ac.id, ${ }^{3}$ liliana.muliastuti@unj.ac.id
}

\begin{tabular}{|c|c|}
\hline Article info & A B S T R A C T \\
\hline $\begin{array}{l}\text { Article history: } \\
\text { Received: 29-07-2018 } \\
\text { Revised : 05-08-2018 } \\
\text { Accepted: } 12-12-2018\end{array}$ & $\begin{array}{l}\text { The purposes of study into identify the needs of Indonesian short story } \\
\text { writing material for foreign students at ACS Jakarta school. The method } \\
\text { used qualitative research. The process of collecting data used } \\
\text { observation activities, interviews, and questionnaire. Validation of data } \\
\text { is triangulation process. The results showed that the foreign students } \\
\text { need materials have a variation level in accordance with the context of } \\
\text { learning which is Indonesian. Students expect Indonesian language short } \\
\text { story writing material that is relevant to their language cultural context } \\
\text { and culture in the Indonesian language. While the teaching materials is } \\
\text { supported by the use of learning media is able to stimulate the learning } \\
\text { activities of writing. }\end{array}$ \\
\hline
\end{tabular}

Keywords:

foreign students

material

needs analysis

short stories

writing

\begin{abstract}
Penelitian ini bertujuan untuk mengidentifikasi kebutuhan bahan ajar menulis cerita pendek bahasa Indonesia bagi siswa penutur asing di sekolah ACS Jakarta. Metode yang digunakan dalam penelitian ini adalah penelitian kualitatif. Proses pengumpulan data menggunakan kegiatan observasi, wawancara, dan kuesioner. Validasi data menggunakan proses triangulasi. Hasil penelitian menunjukkan bahwa siswa penutur asing membutuhkan bahan ajar yang memiliki tingkat variasi sesuai dengan konteks pembelajaran bahasa Indonesia. Para siswa mengharapkan adanya sajian materi ajar menulis cerita pendek yang relevan dengan konteks dan budaya dalam bahasa Indonesia. Selain itu, materi ajar didukung oleh penggunaan media belajar yang mampu menstimulasi kegiatan pembelajaran menulis.
\end{abstract}

Copyright ( 2018 Institut Agama Islam Negeri Syekh Nurjati Cirebon. All rights reserved.

\section{INTRODUCTION}

The learning process requires the materials that match the needs of students and world or global industry. So, to meet those needs, teachers should be able to design and provide these teaching materials. It is to obtain teaching materials that are appropriate to the needs of the student context, teachers can initiate the learning process through needs analysis activities. According to Nunan, needs analysis is a procedure for gathering information about student activities and classroom learning activities for syllabus design needs (Haque, 2014). It can be concluded that the most important part of learning design is the preparation of the needs material that is appropriate with the context. Needs analysis is important in terms of students' involvement in every phase of educational process. It is 


\section{Indonesian Language Education and Literature e-ISSN: 2502-2261 \\ http://www.syekhnurjati.ac.id/jurnal/index.php/jeill/ Vol. 4, No. 1, Desember 2018, 103 - 113}

necessary to know about learners' objectives, language attitudes, expectations from the course and learning habits in order to design an efficient curriculum. There are other factors relevant to the design and implementation of language programs or curricula (Kayi, 2008). Needs analysis is important in terms of students' involvement in every phase of educational process. The studies indicate that it is necessary to know about learners' needs such as their objectives, language attitudes, expectations from the course and learning habits in order to design an efficient curriculum (e.g. Brindley, 1984; Kaur, 2007; Nunan, 1988; Nunan, 1990; Xenodohidis 2002). Those studies are helpful in providing a procedure for using information about learners to inform and guide the course design.

From that view, Indonesian short stories writing learning at ACS Jakarta school for foreign student requires the design of teaching materials in accordance with the background and needs of students. Because Indonesian language as a foreign language is considered difficult to learn for foreign students. If referring to the current curriculum, it should the need for teaching materials must be in accordance with the learning of Indonesian as a foreign language. So, the teachers have to design the teaching materials beginning with the design of syllabus that follow the standard of government. The International Curriculum (e.g IGCSE: International General Certificate Secondary Education issued by Cambridge) used by SPK should refer to the National Education Standards curriculum. The use of a broad curriculum, derived into a syllabus in the learning process. The syllabus developed is the Indonesian Foreign Language syllabus (0545). This syllabus specializes in learning Indonesian for foreign students. After the preparation of the syllabus, teachers can develop teaching materials that can be tailored to the syllabus and exam that will be tested to the students.

The Government of the Republic of Indonesia since 2014 has established cooperation with Cambridge University to create an Indonesian syllabus for Indonesian students. This syllabus is coded 0538 Bahasa Indonesia. However, long before such cooperation, the University of Cambridge has created another syllabus for students who are new to the Indonesian language, called Indonesian Foreign Language / Bahasa Indonesia for Foreign Speakers (Terminology to be used is Bahasa Indonesia untuk Siswa Penutur Asing $(B I P A))$. This syllabus test has been used since 2002. It is one of the syllabus that is known by the top university in the world. The syllabus motivates students to develop lifelong skills of communicating in the Indonesian language. This syllabus has several aims, such as (1) the ability to use a foreign language (Indonesian language) for the practical 


\section{Indonesian Language Education and Literature e-ISSN: 2502-2261 \\ http://www.syekhnurjati.ac.id/jurnal/index.php/jeill/ \\ Vol. 4, No. 1, Desember 2018, 103 - 113}

communication, (2) understanding the culture of the language learned, (3) generating positive thinking about Indonesian culture through the language learned, and (4) communication techniques that can be used in other learning areas such as analytical and rote skills (IGCSE Syllabus 0545).

The result of interview conducted to Indonesian teachers at ACS Jakarta school, it was found that teachers were given only BIPA course syllabus in the learning process. That is, teachers are given the freedom to develop teaching materials in accordance with the signs that should be learned in the classroom. In addition, the source books for foreign students become one of the obstacles that must be faced by ACS Jakarta teachers to deliver Indonesian language materials. Supporting textbooks that are expected to help teachers and students to produce good written products or exam results are not yet available. As a result, teachers must develop their own very extensive teaching materials based on the syllabus already obtained. Currently, teachers who teach BIPA are helped by BIPA (Indonesian for the foreign speaker) books obtained from abroad. The use of the books is in line with the themes in the classroom. One of the books used is the book written by Gwyllam Kay and Jatni Rachmat that published by Nelson, Australia.

In addition to guidebooks, students who learn Indonesian as a foreign language are required to have good writing skills both academic and non-academic writing skills in good structure. In the text, they make are required to have a good groove, the use of correct punctuation and writing, also in accordance with the context requested in the syllabus. Writing student work that is appropriate to the context allows students to dig deeper about the culture and habits owned by the people of Indonesia.

The form of writing that must be mastered by students is narrative writing. Students are asked to write a short article based on a situation / context and students develop the context according to the guidance provided. Narrative writing skills teaching is still very few sources that can be used. As a result, teachers must prepare teaching materials that can develop students' potential to write narration / short stories.

The narrative which is one of the creative writing, can be given to the students of foreign speakers. This will help students to know the expressions in writing. Through creative writing, will improve students' writing skills. The writing skills will increase if there is student involvement to showcase their work (Arshavskaya, 2016). In learning foreign languages, there are several factors that influence the learning outcomes, one of which is the culture. According to Brown, whenever a teacher teaches a language, the 


\section{Indonesian Language Education and Literature \\ e-ISSN: 2502-2261 \\ http://www.syekhnurjati.ac.id/jurnal/index.php/jeill/ \\ Vol. 4, No. 1, Desember 2018, 103 - 113}

teacher also teaches a complex system of cultural habits, values, ways of thinking, feeling, and acting (Brown 2000: 65).

Through language, a person learns a foreign language will gradually learn about the customs, attitudes, and manners of the community. Students will try to adapt to these things through language. Language is a major medium for community members in the process of reception and production of an information, then the culture of a society can develop when supported by the development of language. In the teaching perspective, there are three things developed by creative teaching writing for foreign students, namely: literary and cultural teaching (literary content and context), language learning through diction use and sentence referring to literature, and student creativity learning (use of language style) (Dai \& Li, 2017).

In creative writing, student writing tends to be less contextual in Indonesian culture. Contextual learning is a learning concept that focuses on the close relationships of the real world with students. This learning can make students connect and apply the abilities, they can learn in the classroom about daily life so that students will feel the importance of learning because of the process of applying these competencies. Indonesian writing learning contextually also allows students to learn in a calm and fun because the learning process is done naturally. Writing in Indonesian is closely related to reading ability and particular learning context. Students who learn to write in Indonesian must understand the rhetoric and cultural context of the language learned for more meaningful writing (Myles, 2002). Smith explained that the creative writing curriculum should be given appropriate proportions and recognized so as to provide benefit value for students (Smith, 2013).

The success of a foreign language learning is closely related to the willingness of students. Indonesian learning is as a foreign language is not just memorizing and pronouncing the forms of words and sentences but related to the expected achievement of students especially satisfactory test scores. This success is influenced by motivation, attitude, interests and other factors. At Anglo Chinese School Jakarta, Indonesian language learning as a foreign language is not only taught in the classroom but is developed and socialized as communication media with friends, teachers and staff. Indonesian learning as a foreign language becomes one of the subjects offered by students. Students who come from the Indonesian Foundation and Standard classes when they are in grades 7-8 will be placed in the Indonesian Foreign Language class in grades 9-10. Class division based on students' ability in Indonesian language both written and spoken will make it easier for 
teachers and students in teaching and learning process. In addition, the student's country of origin is also one of the reasons for student placement in the language class. Students who come from Indonesia but make Indonesian as a second language will get the same learning for foreign students who learn Indonesian language. For foreign students, the choice of Indonesian Foreign Language is more appropriate because they use the language for applicative purposes only. In addition to the use of applicative language, the demands requested in the syllabus are not too burdensome for students, especially in written assignments. On the basis of this background exposure, this study examines the need analysis of teaching materials for Indonesian short story writing for foreign students at ACS school Jakarta.

\section{METHOD}

The research method used qualitative research through the narration data obtained from the participants. The sources of participant research data include (a) 10th graders of Indonesian for foreign students of the academic year 2016-2017, (b) teachers who teach Indonesian for foreign students at ACS Jakarta, (c) Indonesian language experts, and (d) Indonesian language learning documents, such as textbooks that are being used in learning. Data were collected through observation, interview, questionnaire, and document analysis. The data obtained will be presented in the form of narrative description to find out the level of students' needs on teaching materials to write short stories of Indonesian language. So, the data validation process through triangulation analysis.

\section{RESULT AND DISCUSSION}

The present study was an attempt to observe and analyze the Indonesian short story writing material that is for foreign student at ACS school Jakarta. Needs analysis activity aims to collect data about the needs of students or schools and instructors of the Indonesian materials that focused on short story writing. Needs analysis is done through the dissemination of questionnaires distributed to students and interview. Questions in needs analysis have 43 questions. Each item of questioning was developed based on the results of initial observation and evaluation of Indonesian learning specifically short story writing for foreign students during this time to the needs of the Indonesian.

Questionnaire Results 


\section{Indonesian Language Education and Literature e-ISSN: 2502-2261 \\ http://www.syekhnurjati.ac.id/jurnal/index.php/jeill/ Vol. 4, No. 1, Desember 2018, 103 - 113}

The questionnaire was administered with the aim of collecting data on the needs of Indonesian short story writing that gave the appropriate with the cross culture language between Indonesia and students' language. The questionnaire contains 3 aspect of Indonesia short story writing needs. Here is the graph of average score that the responses given to the questions on the important aspect of short story writing material.

\section{Material Aspect}

\section{The Average Score Of Material Aspect}

$\longrightarrow$ The average score of material aspect

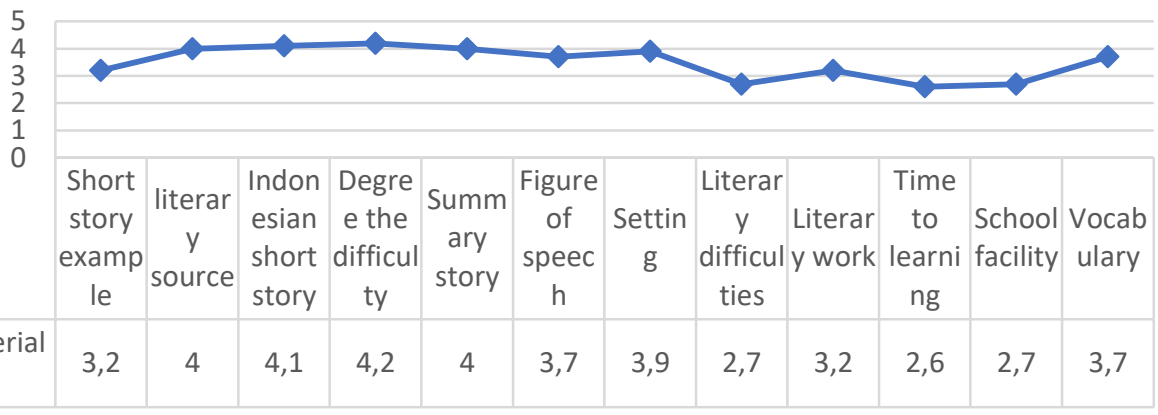

Graph 1. The average score of material needs

It is concluded that the items of requirement analysis questions on the teaching material aspect as a whole have a high score with the required category and are needed. This means that every point of the question indicates the needs of students in Indonesia short story writing learning.

1. Teacher gives examples of short stories that are themed daily life. The first item responded by respondents with the required answers with score 3.2. This means that students prefer the example of short stories taught comes from everyday life. It's easy to understand.

2. Literary learning uses different sources. This question is responded with score of 4 . This means that literary texts have a high degree of difficulty compared to the short story text is not literary.

3. Examples of short stories relating to Indonesian culture responded with score of 4.10. This means that the example of short stories is the culture of Indonesia has more contextual value. It introduces the cultural diversity of the archipelago.

4. Examples of short stories is easy to understand responded with score of 4.20. This means that teachers should find examples of short stories use simple language. 


\section{Indonesian Language Education and Literature e-ISSN: 2502-2261 \\ http://www.syekhnurjati.ac.id/jurnal/index.php/jeill/ \\ Vol. 4, No. 1, Desember 2018, 103 - 113}

5. Students write summary of literary material given by teachers responded with score of 4. This means that teaching materials should encourage students to have initiative in learning.

6. Students can understand the figure of speech responded with score of 3.70 .

7. Students can show the setting contained in the short story easily responded with score of 3.90. It means that teaching materials are presented clearly.

8. Students have difficulties to study the specific of the short story needed responded with score of 2.70 . It means that the literary text material should present an easy-tounderstand.

9. Students understand every of literature that has been given by the teacher responded with score of 3.20. It means that teaching materials are presented easily

10. Students need literary materials to simply answer the questions of the teacher responded with score of 2.60. This means teaching materials should present literary texts stimulate students' desire to answer questions.

11. Students seek literary material for school interest responded with score of 2.70. It means that the literary texts considered only for learning are not so important. Because students need meaningful learning.

12. Through literary works, students know a lot about vocabulary in a language responded with score of 3.70 . It means that teaching materials should provide literary texts that can create students' vocabulary wealth.

\section{Content Aspect}

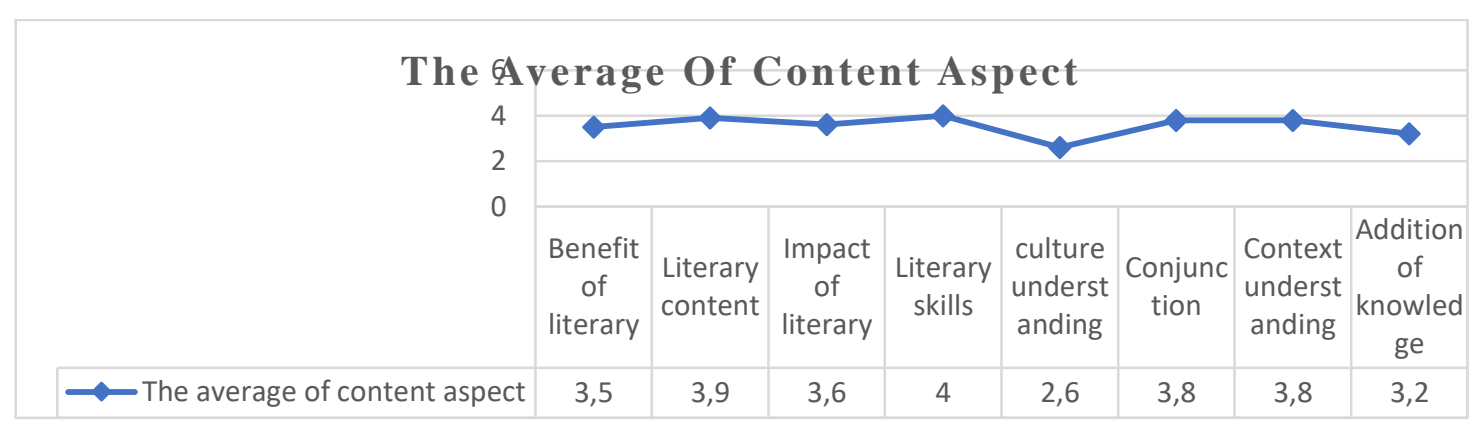

Graph 2. The average score of content needs

From the graph 2 above, it is known that the content aspect consists of 8 questions. Each item has been answered well. From the data analysis concluded the following 


\section{Indonesian Language Education and Literature e-ISSN: 2502-2261 \\ http://www.syekhnurjati.ac.id/jurnal/index.php/jeill/ Vol. 4, No. 1, Desember 2018, 103 - 113}

1. Through learning literature, students easily understand about short stories, poetry and drama responded with score of 3.50. It means that literary texts are capable of providing different knowledge. So, the model of teaching material can modify the literary texts that students can understand easily.

2. Literature lessons make students know the world of literature more detail responded with score of 3.90. It means that the giving of literary texts helps students understand every part or elements of literature.

3. Literature lessons help students get many benefits such as socio-cultural Indonesia responded with score of 4 . This means that students can easily understand the social culture of Indonesia through literary learning. So that students can have an attitude appropriate to the character of Indonesia as mandated in government regulations.

4. Students need literature lessons in the classroom to add literary skills responded with score of 4. It means literary learning can support students' abilities.

5. The Indonesian literary lesson aims to improve the understanding ability of the culture responded with score of 2.60. This means that Indonesian literature gives different colors to the learning of Indonesian culture.

6. Students use the appropriate little hyphen when writing a short story responded with score of 3.80. This means that teaching materials should present material on hyphenes that can help students learn more easily.

7. Students work of short stories is appropriate with the context given by the teacher responded with score of 3.80. This means that teaching materials direct students to create short stories in context.

8. Literary lessons given by teachers can increase students' knowledge about Indonesia's discussion responded with score of 3.20. It means that teaching materials should present useful material.

\section{Learning Process Aspect}

Based on the result of analysis can be concluded that the Indonesian short story writing learning require presentation of learning is harmonious between teaching materials used with the time of learning or use of learning strategies. From the questionnaire analysis that has been given to the students, it is known that the short story skills related to literary texts is the most difficult skill to master. Because the process of writing short stories has many variations and elements that must exist in every writing. 


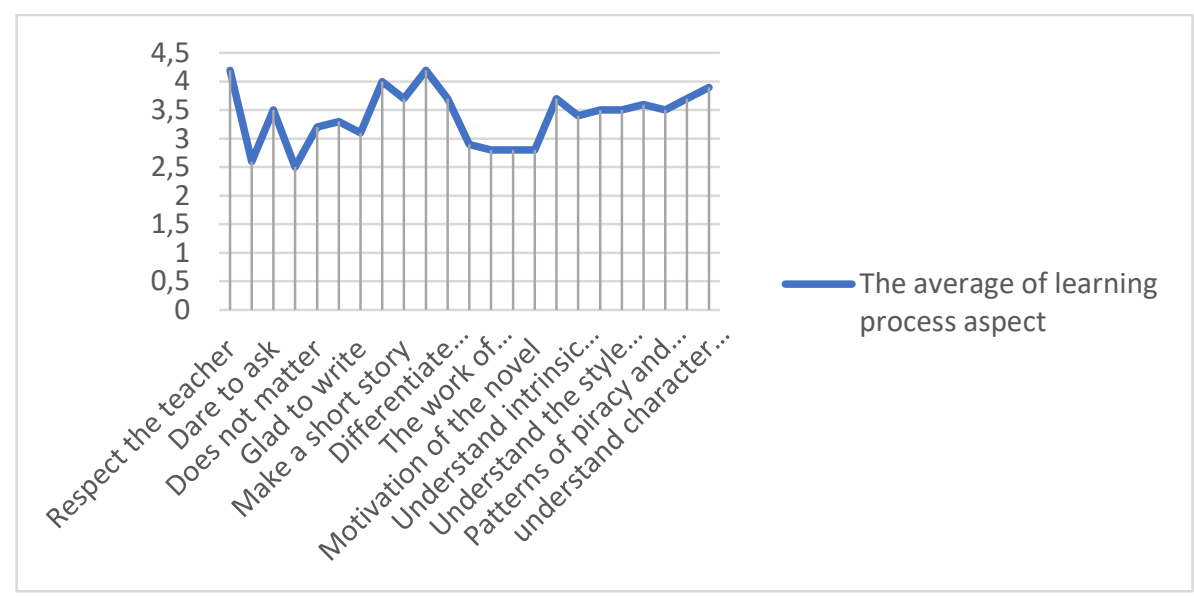

Graph 3. The average score of learning process needs

A student who is able to develop ideas in writing requires a lot of information, so reading activities become an integral part of the right activities to support writing learning. In addition, students can also obtain more in-depth information to support their writing through the activities of listening to many stories or news. Once expressed in writing, students can present the results that can be used as part of the activity to get responses from colleagues or teachers. Because students have more difficulty in expressing and developing their ideas for developing writing. Moreover, the knowledge of students who are still lacking on the culture of Indonesia is also a barrier to the development of writing ideas. Students are still hard to put ideas into Indonesian. So far, their ideas seemed forced on the meaning of Indonesia. Foreign students need a writing lesson that has a contextual value of Indonesian culture.

The above description is part of the view of Indonesian teachers who teach foreign students. The results of discussion with colleagues note that the need for teaching materials to write a short story of Indonesian requires teaching materials that have a cultural context of Indonesia. It aims to make it easier for students to develop ideas and choose the right vocabulary in writing. Thus, teaching materials designed to meet the needs of students. During the learning process, textbook that has used is not appropriate with the students' needs.

Textbooks used for foreign students during at the ACS Jakarta still have many disadvantages. The module used is the development of the teacher. But the use of the book has not resulted in learning. In addition, the source books for foreign students become one of the obstacles that must be faced by teacher at ACS Jakarta to deliver Indonesian 


\section{Indonesian Language Education and Literature e-ISSN: 2502-2261 \\ http://www.syekhnurjati.ac.id/jurnal/index.php/jeill/ \\ Vol. 4, No. 1, Desember 2018, 103 - 113}

materials. Supporting textbooks that are expected to help teachers and students produce good written products or exam results are not yet available. As a result, teachers must develop their own teaching materials based on the syllabus already obtained. Currently, teachers who teach $B I P A$ are helped by $B I P A$ 's books obtained from abroad. The use of the books is in line with the themes learn in the classroom. One of the books used is book written by Gwyllam Kay and Jatni Rachmat and published by Nelson, Australia.

In addition to guidebooks, students who learn Indonesian as a foreign language are required to have good writing skills both academic and non-academic writing skills. In the text, they make are required to have a good setting, the use of correct punctuation and writing, also in accordance with the context requested in the syllabus. Student writing that is appropriate to the context allows to explore deeper about the culture and habits owned by the people of Indonesia.

Referring to evaluation of teaching materials theory from Cunningsworth (1995) generated an analysis that: 1) The learning objectives and approaches have not directly touched on the teaching practice of short stories writing; 2) The design of teaching materials has not provided any special material for Indonesian short story writing because learning materials are still integrated with other language skills; 3) The content of linguistic material is presented as a whole and integrated in language skills. So linguistic materials related to the creative writing skills of short stories are still low; 4) The skills presented in the handbook include four language skills: listening, reading, writing and speaking. 5) The topic has been aligned with the theme learned in the classroom; 6) The methodology has not yet referred to the needs of the practice of short story writing skills; 7) Teachers book are assisted by BIPA obtained from abroad; and 8) Exercise is not only oriented to the creativity of writing short stories. Because in the guidebook, students who learn Indonesian as a foreign language are required to have good writing skills both academic and nonacademic writing skills.

\section{CONCLUSION}

The results of data analysis can be concluded that the foreign students need short story teaching materials. Level of Indonesian short story writing teaching material needs is high which is proved by the acquisition of the average value 3. Students want Indonesian short story writing material that is clear and simple, has context value, stimulating students' creativity in written and a good instructional. Teaching materials in the school do not focus 


\section{Indonesian Language Education and Literature e-ISSN: 2502-2261 \\ http://www.syekhnurjati.ac.id/jurnal/index.php/jeill/ Vol. 4, No. 1, Desember 2018, 103 - 113}

on creative writing learning. Because learning adopts from outside books. So, the context of the learning needs has not been fulfilled.

\section{REFERENCES}

Arshavskaya, E. (2016). Creative Writing Assignments in a Second Language Course: A Way to Engage Less Motivated Students. Retrieved from http://insightjournal.park.edu/wp-content/uploads/2016/04/6-Creative-WritingAssignments-in-a-Second-Language-Course.pdf.

Brown, H. D. (2000). Principles in Language Learning and Teaching-4th Ed. New York: Longman.

Brindley, G. (1984). Needs Analysis and Objective-setting in the Adult Migrant Education Program. Sydney: Adult Migrant Education Service.

Cunningsworth, A. (1995). Choosing your Coursebook. Thailand: Macmillan Heinemann.

Dai, F. \& Li, L. (2017). Teaching creative writing in a foreign language in China, TEXT Special Issue 47: Ideas and Realities: Creative Writing in Asia Today 1 eds Sally Breen and Sanaz Fotouhi.

Haque, N. (2014). A Brief Study on Needs Analysis. Express, an International Journal of Multi Disciplinary Research, 1(1). Retrieved from http://expressjournal.com/pdf/NA.pdf.

Kayi, H. (2008). Developing an ESL Curriculum Based on Needs and Situation Analyses: A Case. Journal of Language and Linguistic Studies, Vol. 4(1)

Kaur, S. (2007). ESP Course Design: Matching Learner Needs to Aims. English for Specific Purposes, Vol. 6(1).

Myles, J. (2002). Second Language Writing and Research: The Writing Process and Errors Analysis in Student Text, Teaching English as a Second/Foreign Language Vol. 6(2).

Nunan, D. (1988). The learner centered curriculum. Cambridge: Cambridge University Press.

Nunan, D. (1990). Using learner data in curriculum development. ESP Journal, Vol. 9, 1732.

Smith, C. (2013). Creative writing as an important tool in second language acquisition and practice. The Journal of Literature in Language Teaching, Vol. 2.

Xenodohidis, T. H. (2002). An ESP Curriculum for Greek EFL Students of Computing: A New Approach. English for Specific Purposes, 1(2). 